\title{
Pengaruh Karakteristik Kewirausahaan, Motivasi, dan Kepemimpinan Transformasional terhadap Keberhasilan Usaha UKM Makanan
}

\author{
Jefferey dan Sarwo \\ Program Studi S1 Manajemen Fakultas Ekonomi \& Bisnis \\ Universitas Tarumanagara \\ Email: jefri.lie98@yahoo.com
}

\begin{abstract}
This study was conducted with the aim to determine the effect of entrepreneurial characteristics, motivation, and transformational leadership on food culinary SMEs in West Jakarta. The sample used in this study was 50 respondents of food culinary SME business owners in West Jakarta was a non-probability sampling method with a purposive sampling technique. This study uses data analysis using Partial Least Square (PLS) which uses the Smart-PLS application version 3.0. The results of this study show the characteristics of entrepreneurship, motivation, and transformational leadership have a positive influence on the success of food culinary SMEs in West Jakarta.
\end{abstract}

Keywords: Characteristics of Entrepreneurship, Motivation, Transformational Leadership, Business Success

Abstrak: Penelitian ini dilakukan dengan tujuan untuk mengetahui pengaruh karakteristik kewirausahaan, motivasi, dan kepemimpinan transformasional pada UKM kuliner makanan di Jakarta Barat.Sampel yang digunakan dalam penelitian ini adalah 50 responden pemilik usaha kuliner kuliner di Jakarta Barat yaitu metode non-probability sampling dengan teknik purposive sampling.Penelitian ini menggunakan analisis data menggunakan Partial Least Square (PLS) yang menggunakan aplikasi Smart-PLS versi 3.0.Hasil penelitian ini menunjukkan karakteristik kewirausahaan, motivasi, dan kepemimpinan transformasional memiliki pengaruh positif terhadap keberhasilan UKM kuliner makanan di Jakarta Barat.

Kata Kunci: Karakteristik Kewirausahaan, Motivasi, Kepemimpinan Transformasional, Keberhasilan Usaha

\section{LATAR BELAKANG}

Pertumbuhan penduduk di Indonesia yang akan datang pasti akan melonjak naik dan semakin meningkat oleh karena itu permasalahan-permasalahan baru akan muncul dan akan berdampak pada perekonomian rakyatnya.Dengan banyaknya jumlah penduduk ini mengharuskan seorang individu harus bisa memulai usaha atau bekerja pada suatu sektor usaha untuk memenuhi kebutuhan hidupnya. Perkembangan aktivitas ekonomi di Indonesia ini dalam tahun terakhir mengalami peningkatan yang signifikan dari tahun-tahun sebelumnya. Sehingga banyak individu-individu kalangan muda seperti mahasiwa atau mahasiswi berani memulai suatu bisnis seperti usaha kecil menengah

UKM dinilai merupakan salah satu solusi terbaik bagi para masyarakat indonesia yang ingin memulai suatu bisnis usaha. UKM ini juga bisa menaikan taraf kehidupan individu tersebut dimana seseorang mampu menciptakan suatu pekerjaan dari sebuah kumpulankumpulan ide unik, terampil sehingga mewujudkan keterampilan tersebut atau keunikanya untuk dijadikan nilai jual.

Mereka sadar akan masalah di indonesia yaitu pengangguran serta minimnya lapangan pekerjaan yang ada dan permasalahan-permasalahan perekonomian di masyarakat. Percaya 
diri, cekatan dan berani mengambil peluang baru merupakan indikator pendukung yang harus bisa dilakukan dan diterapkan agar suatu keberhasilan usaha tersebut dapat diwujudkan dengan nyata serta bukan hanya keinginan saja.

Usaha mikro yang sangat berpotensial di Jakarta Barat yaitu usaha mikro di bidang kuliner makanan, yang kita ketahui di daerah ini terdapat banyak sekali beberapa Food Court yang menyediakan berbagai jenis makanan yang dibuat oleh UKM kecil seperti salah satu contohnya yaitu Totlah. Makanan ini merupakan sejenis rice bowl dengan dipadukan oleh sambal khas Indonesia, ini merupakan salah satu keunikan dimana menggabungkan cita rasa sambal Indonesia dengan khas western.

Kesuksesan UMKM dikaitkan dengan kerja keras, dedikasi, dan komitmen terhadap layanan dan kualitas. Sehingga seoarang individu harus dapat membuat suatu dedikasi kuat seperti mau belajar dan memulai hal yang baru, keinginan untuk maju menjadikan suatu tekanan positif yang mendorong kita untuk terus maju dan berkarya.

Berdasarkan latar belakang di atas, penelitian ini dilakukan dengan beberapa tujuan.Pertama untuk mengetahui pengaruh karakteristik kewirausahaan terhadap keberhasilan usaha UKM.Kedua untuk mengetahui pengaruh motivasi terhadap keberhasilan usaha UKM.Ketiga ntuk mengetahui pengaruh kepemimpinan transformasional terhadap keberhasilan usaha UKM.

\section{KAJIAN TEORI}

Keberhasilan Usaha merujuk pada gabungan antara kemampuan yang kita miliki untuk di implementasikan ke dalam dunia kerja atau dunia usaha yang sebenarnya. Menurut (Yusuf, 1995) "Selain itu manajemen yang baik mengarah pada pembiayaan, kualitas dan kepuasan pribadi dukungan pemerintah juga memainkan peran kunci dalam kesuksesan bisnis".

Karakter kewirausahaan bisa dijadikan salah satu pengaruh dalam keberhasilan usaha.Latar belakang pendidikan pengusaha mengungkapkan bahwa $(72 \%)$ dari pengusaha sukses yang memiliki tingkat minimum kualifikasi teknis, sedangkan sebagian besar (67\%) dari pengusaha yang gagal tidak memiliki latar belakang teknis (Sinha and Tiffany, 1996). Dia menyimpulkan pengusaha itu latar belakang pendidikan bisnis dan teknis berada dalam posisi yang lebih baik dalam pembentukan karakteristik kewirausahaan

Dalam mewujudkan suatu keberhasilan usaha, motivasi usaha dinilai menjadi peran cukup penting bagi seorang individu untuk usaha yang sedang dijalaninya.Menurut Kuratko, et al. (1997) mengklaim bahwa motivasi mengarah pada perilaku yang diarahkan pada tujuan dan keberadaan seperangkat tujuan memotivasi pengusaha untuk mempertahankan upaya pengembangan bisnis mereka.

Kepemimpinan transformasional adalah salah satu proses utama untuk mempengaruhi pengikut dan meningkatkan mereka pengabdian, kesetiaan, kegembiraan dan antusiasme dan itu diakui sebagai dasar kondisi yang diperlukan untuk pengembangan pendekatan kewirausahaan radikal (Eyal \& Kark,2004). Kepemimpinan transformasional dinilai memiliki peran yang cukup penting karena kepemimpinan ini untuk meningkatkan sumber daya manusia dan hubungan antara pemimpin dengan bahwahanya sehingga pemimpin dapat memberikan efek yang positif kepada bawahanya. 
Kerangka pemikiran dalam penelitian ini ada pada Gambar 1.di bawah ini:

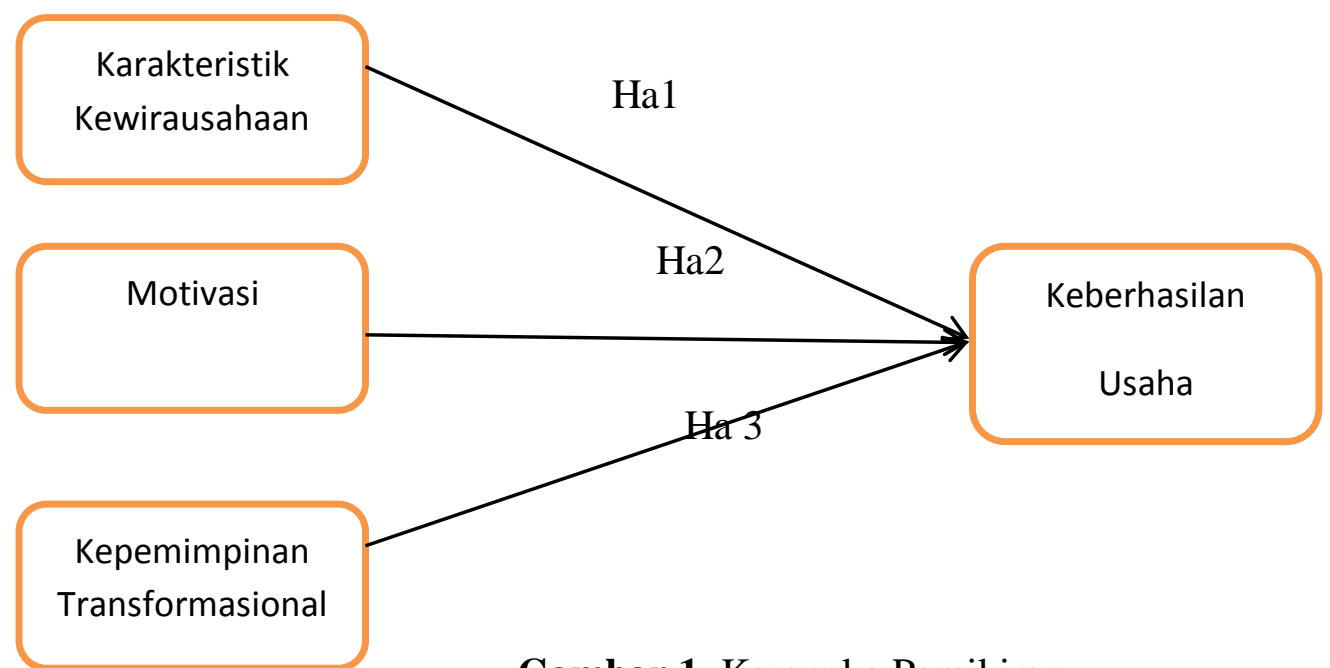

Gambar 1. Kerangka Pemikiran

Berdasarkan peneliti terdahulu yang dilakukan oleh (Hunger \& Wheelen, 2003) menyatakan

"Bahwa ada tiga faktor yang mempengaruhi kinerja usaha kecil, terutama untuk usaha baru. Sesuai dengan tingkat pengaruhnya, faktor-faktor ini adalah struktur industri, strategi bisnis, dan karakteristik wirausaha.Maka dari penjelasan di atas hipotesis penelitian ini dirumuskan sebagai berikut:

Ha1: Karakteristik Kewirausahaan dapat mempengaruhi keberhasilan usaha secara positif.

Motivasi merupakan suatu upaya dorongan yang diberikan dari faktor luar atau dalam yang diterima oleh seorang individu untuk dijadikan pedoman atau arahan untuk menjadi maju kearah yang lebih baik. Motivasi yang kita dapatkan sangatlah bermanfaat terhadap keinginan untuk mencapai prestasi dalam wirausaha yang sedang dijalankan. Teori tersebut didukung dengan hasil penelitian Anggraeni (2017), Purnama dkk (2010), Yusniar (2017) dan Farida dkk (2015) bahwa motivasi memiliki pengaruh positif dan signifikan terhadap keberhasilan usaha.Maka dari penjelasan di atas hipotesis penelitian ini dirumuskan sebagai berikut:

Ha2: Motivasi dapat mempengaruhi keberhasilan usaha secara positif.

Berdasarkan peneliti terdahulu yang dilakukan oleh Wirjana and Supardo (2006: 20) menyatakan " That leadership is actions by a person or some people who influence someone's behavior or deeper a group". Kepemimpinan transformasional yang dijalankan pada wirausaha membuat perubahan kesadaran akan lingkungan sekitar serta lebih mengetahui akan faktor-faktor apa saja yang dapat membangkitkan semangat antara bawahan dengan para pemimpin sehingga tujuan organisasi atau wirausaha dapat dianggap berjalan dengan baik dan efektif. Maka dari penjelasan di atas hipotesis penelitian ini dirumuskan sebagai berikut:

Ha3: Kepemimpinan transformasional dapat mempengaruhi keberhasilan usaha secara positif

\section{METODOLOGI}

Jumlah responden dalam penelitian ini adalah sebanyak 50 responden yang diambil dari para pemilik UKM di Jakarta Barat.Teknik pengambilan sampel yang digunakan dalam penelitian ini yaitu teknik purposive sampling.Desain penelitian yang akan peneliti gunakan adalah desain penelitian konklusif yang terdiri dari penelitian deskriptif dan penelitian kausal 
atau bisa dapat disebut penelitian eskperimental.Dalam penelitian ini, peneliti menggunakan metode kuantitatif karena metode kuantitatif merupakan proses menemukan pengetahuan yang menggunakan data berupa angka sebagai alat menganalisis keterangan mengenai apa yang ingin diketahui (Kasiram, 2008). Instrumen dalam penelitian ini menggunakan kuesioner dengan secara langsung maupun secara online web google form.Data diolah menggunakan aplikasi SmartPLS 3.0 dengan metode partial least square (PLS).

Penelitian ini menggunakan empat variabel yaitu, variabel karakteristik kewirausahaan, variabel motivasi, variabel kepemimpinan transformasional, dan variabel keberhasilan usaha.Karakteristik kewirausahaan memiliki 13 item pertanyaan, motivasi memiliki 8 item pertanyaan, kepemimpinan transformasional memiliki 5 item pertanyaan, dan keberhasilan usaha memiliki 5 item pertanyaan.

\section{HASIL UJI STATISTIK}

Pengujian hipotesis penelitian ini menggunakan $P L S$ yang terdiri atas uji validitas, uji reliabilitas, uji koefisien determinasi (R2), uji pengukuran $Q$-Square, uji GoF, dan uji hipotesis.

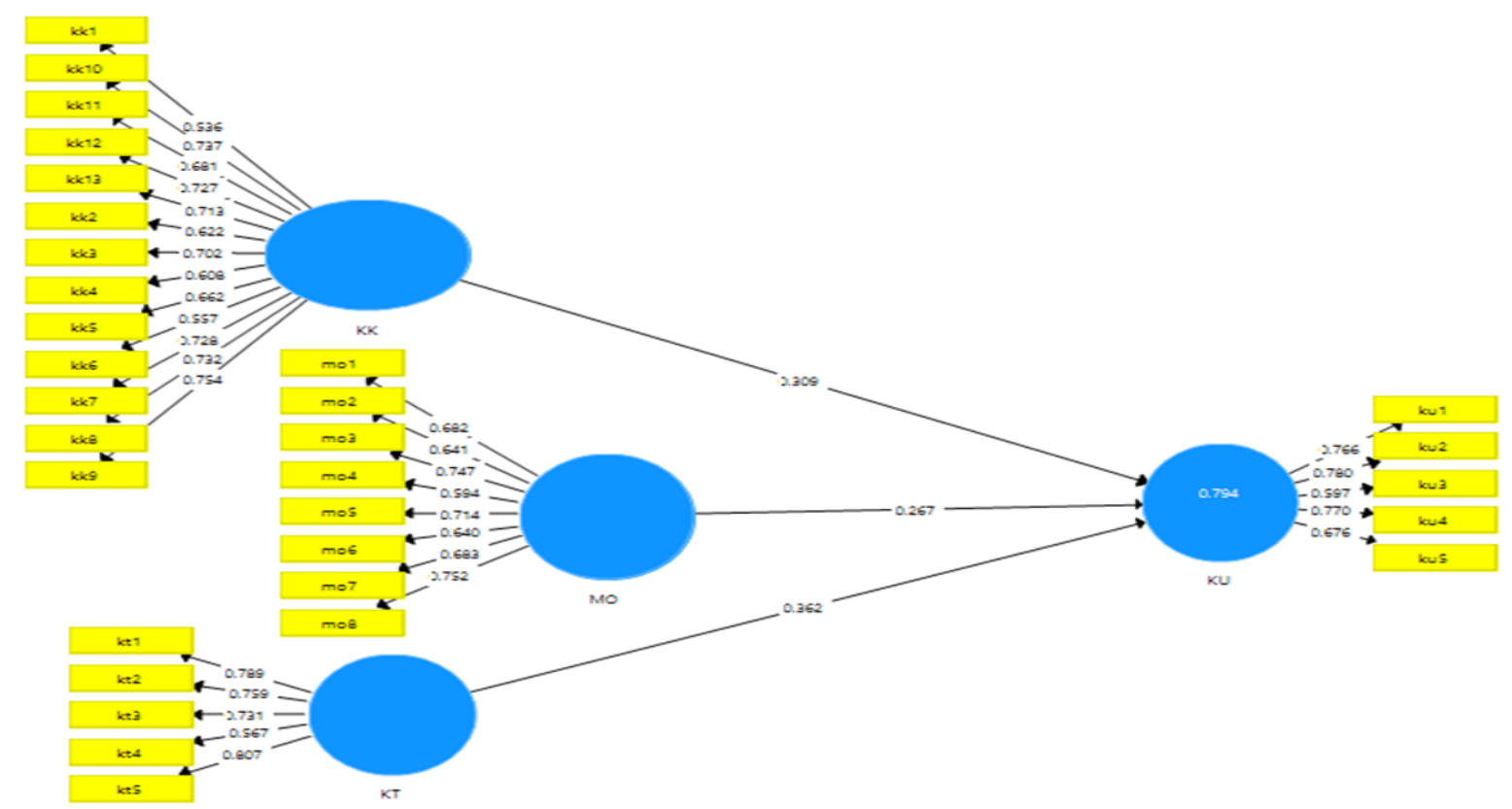

Gambar 2. Hasil Outer loading SmartPLS 


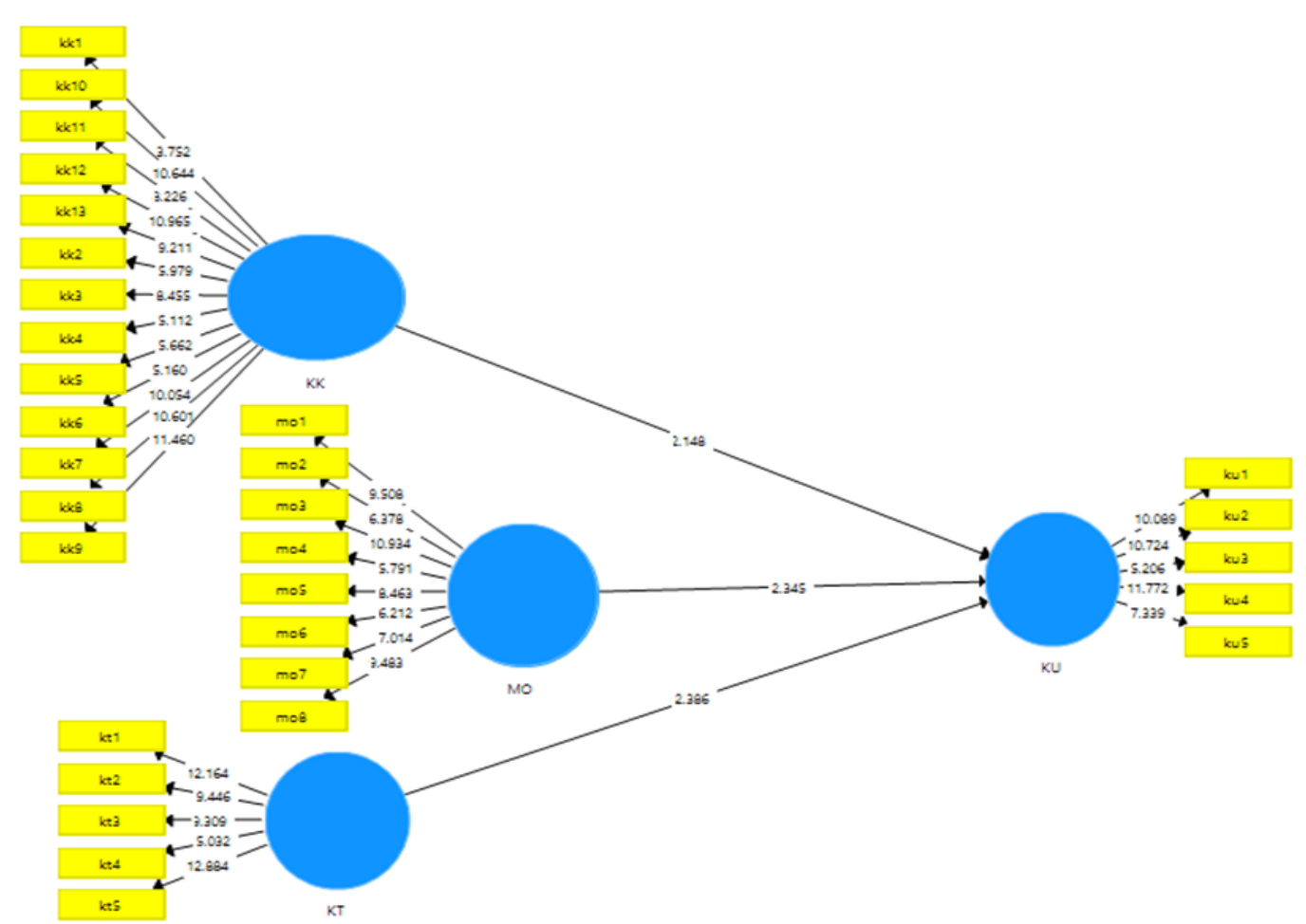

Gambar 3. Hasil Uji Bootstrapping

Gambar diatas akan membahas tentang hasil pengolahan data dengan software SmartPLS yaitu:

Uji Validitas

\begin{tabular}{|l|l|l|l|l|}
\hline Variabel & $\begin{array}{l}\text { Karakteristik } \\
\text { Kewirausahaan }\end{array}$ & Motivasi & $\begin{array}{l}\text { Kepemimpinan } \\
\text { Transformasional }\end{array}$ & $\begin{array}{l}\text { Keberhasilan } \\
\text { Usaha }\end{array}$ \\
\hline $\begin{array}{l}\text { Karakteristik } \\
\text { Kewirausahaan }\end{array}$ & $\mathbf{0 , 6 7 7}$ & & & \\
\hline Motivasi & 0,806 & $\mathbf{0 , 6 8 4}$ & & \\
\hline $\begin{array}{l}\text { Kepemimpinan } \\
\text { Transformasional }\end{array}$ & 0,888 & 0,841 & $\mathbf{0 , 7 3 6}$ & \\
\hline Keberhasilan Usaha & 0,846 & 0,821 & 0,862 & $\mathbf{0 , 7 2 1}$ \\
\hline
\end{tabular}

Hasil validitas deskriminan menunjukkan nilai akar AVE tiap variabelnya lebih besar dari 0,50 hal ini mengindikasikan persyaratan validitas deskriminan yang baik.

Uji Reliabilitas

\begin{tabular}{|l|l|l|l|}
\hline Variabel & Composite Reliability & Cronbach's alpha & Keterangan \\
\hline Karakteristik Kewirausahaan & 0,916 & 0,900 & Reliabel \\
\hline Motivasi & 0,875 & 0,837 & Reliabel \\
\hline $\begin{array}{l}\text { Kepemimpinan } \\
\text { Transformasional }\end{array}$ & 0,853 & 0,785 & Reliabel \\
\hline Keberhasilan Usaha & 0,843 & 0,767 & Reliabel \\
\hline
\end{tabular}

Hasil menunjukan hasil pengujian reliabilitas dengan nilai yang tinggi dari batas ketentuan, yaitu semua variabel laten telah reliabel karena seluruh nilai variabel laten memiliki nilai composite reliability dan Cronbach's alpha $\geq 0,70$. 
Uji Koefisien Determinasi $(R 2)$

\begin{tabular}{|l|l|l|}
\hline Variabel & R-Square & R-Square(\%) \\
\hline Keberhasilan usaha UKM (Y) & 0,794 & $79,4 \%$ \\
\hline
\end{tabular}

Hasil menunjukan nilai $\mathrm{R}$ square adalah sebesar 0,794 yang berarti besarnya pengaruh motivasi, karakteristik kewirausahaan, dan kepemimpinan transformasional terhadap keberhasilan usaha UKM adalah sebesar 79,4\%, sedangkan sisanya (100\%-79,4\%) sebesar $20,6 \%$ keberhasilan usaha UKM dipengaruhi oleh variabel lain yang tidak terdapat di dalam penelitian ini.

Uji Pengukuran $Q$-Square (Q2)

\begin{tabular}{|l|l|}
\hline Variabel & Q-Square \\
\hline Keberhasilan usaha UKM (Y) & 0,381 \\
\hline
\end{tabular}

Hasil menunjukan bahwa variabel motivasi, karakteristik kewirausahaan, dan kepemimpinan transformasional memiliki pengaruh terhadap keberhasilan usaha UKM yaitu sebesar 0,381 .

Uji Kecocokan Model (Goodness of Fit/GoF)

\begin{tabular}{|l|l|}
\hline Variabel & Average Variance Extracted $(A V E)$ \\
\hline Karakteristik Kewirausahaan & 0,459 \\
\hline Motivasi & 0,467 \\
\hline Kepemimpinan Transformasional & 0,541 \\
\hline Keberhasilan Usaha & 0,520 \\
\hline Rata-rata nilai $A V E$ dari keempat variabel & $\mathbf{0 , 4 9 7}$ \\
\hline $\mathrm{R}^{2}$ & 0,794 \\
\hline
\end{tabular}

$$
\begin{aligned}
& \text { GoF }=\sqrt{A V E \times R^{2}} \\
& \text { GoF }=\sqrt{0,497 \times 0,794} \\
& \text { GoF }=\sqrt{0,394} \\
& \text { GoF }=0,628
\end{aligned}
$$

Hasil perhitungan nilai GoF dari nilai AVE dan $\mathrm{R}^{2}$ dengan perhitungan manual dengan rumus, diperoleh hasil perhitungan Goodness of Fit $(G o F)$ sebesar 0,628. Nilai GoF sebesar 0,628 di atas 0,360 sehingga dapat disimpulkan nilai GoF model yang digunakan di dalam penelitian ini merupakan kecocokan model penelitian yang tergolong besar.

Uji Hipotesis (Path Coefficient)

\begin{tabular}{|l|l|l|l|}
\hline Variabel & $\begin{array}{l}\text { Original } \\
\text { Sample }\end{array}$ & T-Statistics & P-Values \\
\hline $\begin{array}{l}\text { Karakteristik Kewirausahaan } \\
\text { Keberhasilan usaha UKM (Y) }\end{array}$ & 0,309 & 2,148 & 0,016 \\
\hline $\begin{array}{l}\text { Motivasi (X) } \rightarrow \text { Keberhasilan usaha } \\
\text { UKM (Y) }\end{array}$ & 0,267 & 2,345 & 0,010 \\
\hline $\begin{array}{l}\text { Kepemimpinan Transformasional }\left(\mathrm{X}_{3}\right) \rightarrow \\
\text { Keberhasilan usaha UKM (Y) }\end{array}$ & 0,362 & 2,386 & 0,009 \\
\hline
\end{tabular}


Pengujian hipotesis pada penelitian ini digunakan untuk melihat hubungan antara variabel dengan melihat hasil dari metode bootstrapping bagian t-statistic dan p-values. Jika nilai tstatistic lebih besar dari 1,96 atau $\mathrm{p}$ values $<0,05$ maka $\mathrm{H} 0$ ditolak dan dapat dikatakan bahwa variabel independen $(\mathrm{X})$ berhubungan secara signifikan terhadap variabel dependen $(\mathrm{Y})$.

\section{Pembahasan}

Koefisien determinasi digunakan untuk mengetahui seberapa besar kontribusi dari variabel independent karakteristik kewirausahaan, motivasi, dan kepemimpinan transformasional terhadap variabel dependen keberhasilan usaha pada UKM. Hasil dari pengujian koefisien determinasi (R2) dalam penelitian ini adalah sebesar 0,794 atau 79,4\%.

Berdasarkan hasil pengujian koefisien determinasi dari table diatas selanjutnya akan dihitung. Maka nilai $R$-square adalah sebesar 0,794 yang berarti besarnya pengaruh motivasi, karakteristik kewirausahaan, dan kepemimpinan transformasional terhadap keberhasilan usaha UKM adalah sebesar 79,4\%, sedangkan sisanya (100\%-79,4\%) sebesar 20,6\% keberhasilan usaha UKM dipengaruhi oleh variabel lain yang tidak terdapat di dalam penelitian ini.

Tahap selanjutnya mengenai analisi variabel yang sama. Sehinga peneliti selanjutnya melakukan pengujian Goodness of Fit $(G o F)$, pengujian tersebut dilakukan untuk mengetahui kecocokan dari model yang terdapat dalam penelitian ini dengan hasil perhitungan Goodness of Fit (GoF), yaitu sebesar 0.628.

Peneliti juga mengolah data menggunakan SmartPLS. Sehingga peneliti menemukan hasil olah data path coefficient pada tabel 4.11 di atas, maka persamaan dalam penelitian ini yaitu Keberhasilan usaha UKM $(Y)=0,309$ Karakteristik Kewirausahaan + 0,267 Motivasi + 0,362 Kepemimpinan Transformasional.

\section{Ha1: Karakteristik Kewirausahaan Dapat Memengaruhi Keberhasilan Usaha Secara Positif}

Hasil uji hipotesis pertama menunjukan nilai koefisien karakteristik kewirausahaan terhadap keberhasilan usaha UKM dengan nilai 0,309. Hasil nilai koefisien bertanda positif sehingga dapat disimpulkan bahwa hubungan antara kedua variabel adalah searah, artinya semakin baik karakteristik kewirausahaan maka semakin baik pula keberhasilan usaha UKM.

Berdasarkan hasil pengujian variabel karakteristik kewirausahaan terhadap keberhasilan usaha UKM menunjukan nilai $T$-statistic lebih besar dari 1,96 yaitu sebesar 2,148 dan nilai $P$ values lebih kecil dari 0,05 yaitu sebesar 0,016, artinya karakteristik kewirausahaan memiliki pengaruh yang positif terhadap keberhasilan usaha UKM. Sehingga Ha1 yang menyatakan "Karakteristik Kewirausahaan dapat mempengaruhi Keberhasilan Usaha secara positif" di terima.Hasil penelitian ini searah dengan penelitian( Hunger\& Wheelen, 2003)yang menyatakan bahwa karakteristik kewirausahaan berpengaruh secara positif dan signifikan terhadap keberhasilan usaha

\section{Ha2: Motivasi Dapat Memengaruhi Keberhasilan Usaha Secara Positif}

Hasil uji hipotesis kedua menunjukan nilai koefisien motivasi terhadap keberhasilan usaha UKM dengan nilai 0,267. Hasil nilai koefisien bertanda positif sehingga dapat disimpulkan bahwa hubungan antara kedua variabel adalah searah, artinya semakin baik motivasi maka semakin baik pula keberhasilan usaha UKM.Berdasarkan hasil pengujian variabel motivasi terhadap keberhasilan usaha UKM menunjukan nilai $T$-statistic lebih besar dari 1,96 yaitu sebesar 2,345dan nilai $P$-values lebih kecil dari 0,05 yaitu sebesar 0,010 , artinya motivasi memiliki pengaruh yang positif terhadap keberhasilan usaha UKM.Sehingga Ha2 yang menyatakan "Motivasi dapat mempengaruhi Keberhasilan Usaha secara positif" di 
terima.Hasil penelitian ini searah dengan penelitianAnggraeni (2017), Purnama dkk (2010), Yusniar (2017) dan Farida dkk (2015) yang menyatakan bahwa motivasi berpengaruh secara positif dan signifikan terhadap keberhasilan usaha

\section{Ha3: Kepemimpinan Transformasional Dapat Memengaruhi Keberhasilan Usaha Secara Positif}

Hasil uji hipotesis ketiga menunjukan nilai koefisien kepemimpinan transformasional terhadap keberhasilan usaha UKM dengan nilai 0,362. Hasil nilai koefisien bertanda positif sehingga dapat disimpulkan bahwa hubungan antara kedua variabel adalah searah, artinya semakin baik kepemimpinan transformasional maka semakin baik pula keberhasilan usaha UKM.

Berdasarkan hasil pengujian variabel kepemimpinan transformasional terhadap keberhasilan usaha UKM menunjukan nilai T-statistic lebih besar dari 1,96 yaitu sebesar 2,386 dan nilai $P$-values lebih kecil dari 0,05 yaitu sebesar 0,009 , artinya kepemimpinan transformasional memiliki pengaruh yang positif terhadap keberhasilan usaha UKM. Sehingga Ha3 yang menyatakan "Kepemimpinan transformasional dapat mempengaruhi Keberhasilan Usaha secara positif" di terima.Hasil penelitian ini searah dengan penelitian (Wirjana and Supardo (2006: 20) yang menyatakan bahwa kepemimpinan transformasional berpengaruh secara positif dan signifikan terhadap keberhasilan usaha

\section{Kesimpulan} berikut:

Berdasarkan hasil analisis yang peneliti teliti, maka dapat ditarik kesimpulan sebagai

1. Karakteristik kewirausahaan memiliki pengaruh yang positif terhadap keberhasilan usaha

2. Motivasi memiliki pengaruh yang positif terhadap keberhasilan usaha

3. Kepemimpinan Transformasional memiliki pengaruh yang positif terhadap keberhasilan usaha

Berdasarkan hasil penelitian yang telah diperoleh, maka peneliti dapat memberikan

Beberapa saran yang dapat bermanfaat sebagai berikut:

1. Bagi Akademis mahasiswa/i harus memiliki mindset atau pola pikir untuk menjadi seorang wirausaha, membantu negara untuk membuka lapangan pekerjaan, lebih bisa menggali lagi cara mengembangkan usaha atau tahapan berwirausaha agar keberhasilan usaha dapat berjalan dengan sukses.

2. Bagi Pemerintah Daerah (praktisi), membentuk sebuah tim atau kelompok usaha harus dengan keterbukaaan atau transparansi yang jelas antar paguyupan kelompok UKM, agar tidak ada yang salah paham, dan harus berkomunikasi dengan baik agar jika terjadi kesalahan dapat segera diperbaiki bersama-sama pemilik UKM agar menjadi lebi baik.

3. Bagi masyarakat disarankan membuka wawasan lebih luas dengan selalu menambah pengetahuan dan informasi untuk tertarik dan memiliki minat kuat untuk membuka bisnis sendiri mulai dari menekuni usaha kecil dan menengah (UKM) dengan cara mengikuti pelatihan atau seminar kewirausahaan yang dilakukan instansi atau pemerintah daerah, sehingga akan tertarik dan memiliki minat yang kuat dalam membuka usaha. 


\section{DAFTAR PUSTAKA}

Eyal, O.,\& Kark, R. (2004).How do transformational leaders transform organisations? A study of the relationship between leadership and entrepreneurship.Journal Leadership and Policy in Schools, 3(3):211-235.

Farida, E., \& Widayanti, R. (2015).Analisis Pengaruh Motivasi, Kemampuan Kerja dan Jiwa Wirausaha terhadap Keberhasilan Usaha pada Sentra Kripik Tempe Sanan Malang. Journal Akutansi Bisnis \& Manajemen (ABM), 22(1), 50-59.

Hunger, J.D., dan Thomas L.W. (2003).Management Strategis.Terjemahan Julianto Agung. Edisi 2, Andi, Yogyakarta.

Kuratko, D.F., Hornsby, J.S. dan Naffzigar, D.W. (1997).An examination of owner"s goals in sustaining entrepreneurship.Journal of Small Business Management, Vol. 35 No. 1, hal.24-33.

Moh, K. (2010), Metodologi Penelitian Kualitatif-Kuantitatif. Malang: UIN Maliki Press 2010.

Sinha, T.N. (1996). " Human factors in entrepreneurship effectiveness". Journal of Entrepreneurship. 5(1),23-29.

Wirjana, B. R., dan Supardo, S. (2010). Kepemimpinan, Cetakan Pertama, Penerbit Andi, Yogyakarta

Yusuf, A. (1995). Critical Success Factors for Small Business: Perceptions of South Pacific Entrepreneurs.Journal of Small Business Management, 33(2), 68 